\title{
A HOLISTIC APPROACH TO WORKPLACE STRESS MANAGEMENT
}

\author{
Jelena Lukić* \\ Modern Business School \\ Belgrade, Republic of Serbia \\ Snežana Lazarević \\ College of Sports and Health \\ Belgrade, Republic of Serbia
}

\begin{abstract}
Workplace stress is a field of research interest of the academic community, but also of many human resource experts, since it has been realized that stress negatively affects the overall functioning of organizations and their business results. During the process of eliminating and/or reducing stress at the workplace, human resource experts should consider several factors and design adequate methods and techniques for stress management. The aim of this paper is to examine and point out the importance of a holistic approach to managing the issue of stress at the workplace. This paper presents methods and techniques for eliminating stress regarding the level at which they are applied (individual and organizational level) and regarding the time of the application (primary, secondary and tertiary). Stress management should be an integral part of organizational behavior and should include all business processes and activities in the organization.
\end{abstract}

Key words: stress, employee, workplace, stressor, stress management, human resource management, organizational behavior

JEL classification: J81, M12, M54

\section{HOLISTIČKI PRISTUP UPRAVLJANJU STRESOM NA RADNOM MESTU}

Sažetak: Stres na radnom mestu predstavlja predmet interesovanja akademske zajednice, ali $i$ mnogih stručnjaka za ljudske resurse, jer je uočeno da se stres kod zaposlenih negativno odražava na njihove poslovne rezultate, ali $i$ na celokupno

\footnotetext{
*jelena.lukic@mbs.edu.rs
} 
funkcionisanje organizacije. U procesu eliminisanja i/ili smanjenja stresa na radnom mestu, stručnjaci iz oblasti ljudskih resursa moraju da uzmu u obzir više faktora i da primene adekvatne metode i tehnike. Cilj ovog rada jeste da ukaže na značaj holističkog pristupa prilikom upravljanja stresom na radnom mestu. $U$ radu su prikazane metode $i$ tehnike za eliminisanje $i$ smanjenje stresa na radnom mestu, u odnosu na nivo na kojem se primenjuju (individualni nivo i nivo organizacije), i u zavisnosti od vremena njihove primene (primarno, sekundarno i tercijarno). Upravljanje stresom treba da bude sastavni deo funkcionisanja svake organizacije $i$ da obuhvati sve njene segmente, procese i aktivnosti.

Ključne reči: stres, zaposleni, radno mesto, stresori, upravljanje stresom, upravljanje ljudskim resursima, organizaciono ponašanje

\section{INTRODUCTION}

Globalization and technological advancement have led to numerous changes in the functioning and managing of organizations, as well as the way their business processes and employees are organized. Organizations have become agile and flexible, free from traditional hierarchical structures, with largerly decentralized decision-making process, while employees are expected to have a greater degree of innovation, collaboration, knowledge and experience sharing, and teamwork skills (Petković and Lukić, 2014; Lazarević and Lukić, 2018). Many organizations use modern forms of employment, such as remote work, in which geographically separated employees are members of a virtual team working on the implementation of arranged projects (Lukić and Vračar, 2018). All these trends characterize the modern job market and represent the ideal that every organization strives for in order to improve its business results. However, it is a fact that an increasing number of employees feel stressed (Holton, Barry and Chaney, 2016). Workplace stress has detrimental physical and psychological effects on employees, due to the increasing demands at work which exceed their knowledge, skills, and abilities (NIOSH - The National Institute for Occupational Safety and Health, 1999). Lazarus and Folkman define stress as the relationship between the individual and the environment and point out that stress occurs when people perceive that the demands from external situations are beyond their coping capacity (Lazarus and Folkman, 2004). Although workplace stress represents only one of the possible forms of stress that a person may be exposed to, it is one of the most pronounced forms of stress as employees spend most of their time in the workplace (Britt and Jex, 2015).

In recent years, it has been noticed that all employees face workplace stress, regardless of their profession and position (Valcik and Benavide, 2011; Claridge and Cooper, 2014). Even jobs that do not seem stressful at first can have different sources and forms of stress because no organization functions 
autarchically without contact with the environment and various stakeholders (Kompier and Kristensen, 2001).

Many studies have shown that stress has negative effects not only on employees but also on the overall functioning of organizations and their business results (Munz, Kohler and Greenberg, 2001; Ongori and Agolla, 2008; Richardson and Rothstein, 2008). For this reason, workplace stress has become the research subject of the academic community, but also a concern of many human resource professionals. However, many authors dealing with this topic have often neglected the fact that the negative effects of workplace stress should be viewed from multiple perspectives and that a holistic approach should be applied in the stress management process.

The aim of this paper is to present workplace stress management methods and techniques from multiple perspectives. One of the perspectives that will be presented in the paper refers to the level at which measures and techniques of stress management (individual and organizational level) are applied, while the other perspective relates to the time of their application (primary, secondary, and tertiary).

\section{THE ANALYSIS OF KEY NEGATIVE EFFECTS OF WORKPLACE STRESS}

Every organization consists of people who aim to achieve their professional goals, and many of them get emotionally attached to their jobs, management, and colleagues (Petković and Lukić, 2013). Employees are perceived as the most important factor in the functioning of every organization, because business results depend on the quality of their work. Organizational changes, transformations, mergers, acquisitions, takeovers, constant pressures to reduce operating costs, increase efficiency and effectiveness create pressure on employees and cause stress. There can be multiple stressors in the workplace, that is, factors that have a negative effect on employees and can lead to stress. Stressors may originate from: (1) workplace physical conditions (temperature, lighting, noise, cleanliness); (2) interpersonal relationships (relationships with superiors and colleagues, degree of empathy); (3) personal characteristics of each employee (individual employee differences, particular moods or conditions); (4) work tasks (the nature of task, task complexity and meaningfulness); (5) the role of the employee in the organization (the employee's position in accordance with his knowledge, skills and affinities, the clarity and unambiguity of the role) (Wagner and Hollenbeck, 2002).

The consequences of workplace stress are not only reflected on employees who are exposed to stress, but there are numerous negative effects throughout the entire organization (Childs and Stoeber, 2012). Stress, in addition to 
physiological and affective reactions, leads to poor social functioning of the individual (Lazarus, 1991). Table 1 provides an overview of the key psychological and physiological consequences of stress on employees.

Table 1

A review of the psychological and physiological consequences of stress on employees

\begin{tabular}{|l|l|}
\hline $\begin{array}{c}\text { Psychological consequences } \\
\text { of stress }\end{array}$ & \multicolumn{1}{|c|}{$\begin{array}{c}\text { Physiological consequences } \\
\text { of stress }\end{array}$} \\
\hline Anxiety & $\begin{array}{l}\text { Insomnia } \\
\text { Pension }\end{array}$ \\
Dissatisfaction & Headaches \\
Depression & Heat stroke and shivers \\
Frustration & Eye blinking \\
Lethargy & Tinnitus \\
Forgetfulness & Appetite changes \\
Lack of concentration & Fatigue, apathy \\
Loss of humor & $\begin{array}{l}\text { Increased blood pressure and } \\
\text { tachycardia }\end{array}$ \\
\hline
\end{tabular}

Note. Britt, T. W., \& Jex, S. M. (2015). Thriving under Stress, Harnessing Demands in the Workplace. Oxford: Oxford University Press.

Workplace stress negatively affects productivity, level of satisfaction, motivation, absenteeism, and employee fluctuation (Mequilibrium, 2013; Balkan and Serin, 2014; Jetha, Kernan and Kurowski, 2017). Stressed employees have less confidence, poor communication intensity with other employees in the organization, and poor client relationships (Karunanithy and Ponnampalam, 2013; Stickle and Scott, 2016). In addition, stress negatively affects concentration, decision-making process, employee motivation, and morale (Dar, Akmal, Naseem and Khan, 2011). Due to the effects of stress, an increasing number of employees are turning to vices (cigarettes and alcohol) or beginning to act counterproductively ("shirking duties" when working or delaying activities), which also has a negative impact on business results (Stranks, 2005).

Many studies have shown that stress increase leads to a decrease in employee performance and, consequently, the results of the organization itself (Tillman, Hamill, Dungan, Lopez, Lu and Limeade, 2017). It is estimated that costs 
incurred as a result of stress in organizations are measured in billions of dollars (Johns, 2010). In situations where the organization's top executives begin to cope with the first signs of stress which are caused by the way their business is conceived and the organizational context, they start to look for another job, and the organization faces additional costs of recruiting and selecting new employees (Ongori, 2007; Mequilibrium, 2013). Also, there is a great number of customer objections and complaints in many organizations in the service sector about employees who are stressed (Stranks, 2005).

\section{THE ANALYSIS OF DIFFERENT WORKPLACE STRESS MANAGEMENT PERSPECTIVES}

It is certain that increasing work demands and pressure to achieve better results will be an integral part of life and work in the future. Proper stress management will become a condicio sine quo non for a healthy and harmonious life, but also for achieving business results (Lukić and Lazarević, 2018). The aspiration of every organization is to have a greater number of employees that are "resilient to stressful situations". These employees are more likely to cope with stressful situations due to optimism, focus on important activities and goals, flexibility, organization, and proactive attitude (Risher and Stopper, 1999). Not only do they have a greater degree of confidence and self-efficiency, but they also relieve workplace stress fast (Maddi and Khoshaba, 2005; Beltman, Mansfield and Price, 2011).

Human resources experts started to conceptualize and implement various stress management methods and techniques, with the aim of eliminating and/or reducing the negative effects and consequences of stress on employees and their productivity. Stress management methods and techniques include any activity, technique or program that an organization implements to eliminate and/or reduce stressors and help employees cope with stress (Ivancevich, Matteson, Freedman and Phillips, 1990). The concept of stress management itself comprises: (1) eliminating/reducing stressors; (2) decreasing the intensity of stressors; (3) helping employees to overcome problems caused by stress (Grawitch, Ballard and Erb, 2015).

The application of stress management methods and techniques has proven to be good in practice, as the employee health care expenditures have been reduced and productivity increased (Mills, Kessler, Cooper and Sullivan, 2007). In addition, the benefits of stress management for the organization are: focused employees, a sense of community and trust in the workplace, better interpersonal relationships, less employee absenteeism and fluctuation, and better communication between employees from different organizational units (Stranks, 2005). 
The methods and techniques used to manage workplace stress should be viewed from multiple perspectives. In this paper, two perspectives will be used to review stress management methods and techniques. One perspective refers to the level at which the methods and techniques are applied - the organizational level and individual level, while the other perspective refers to the time of the application of anti-stress methods and techniques, which can be primary, secondary and tertiary (Table 2).

Table 2

The methods and techniques for eliminating and reducing stress from two perspectives

\begin{tabular}{|l|l|}
\hline $\begin{array}{c}\text { Time of application of methods and } \\
\text { techniques }\end{array}$ & \multicolumn{1}{|c|}{$\begin{array}{c}\text { Scope of methods and } \\
\text { techniques }\end{array}$} \\
\hline $\begin{array}{l}\text { Primary methods and techniques } \\
\text { Secondary methods and techniques } \\
\text { Tertiary methods and techniques }\end{array}$ & $\begin{array}{l}\text { Organizational level } \\
\text { Individual level }\end{array}$ \\
\hline
\end{tabular}

Note. Brun, J.P., \& Martel, J. (2005). Mental Health at Work - From Defining to Solving the Problem - Preventing stress in the workplace, Booklet 3, a Series Mental Health at Work, Universite Laval.

At the organizational level, it is necessary to eliminate or reduce the occurrence and effect of stressors in all possible segments. However, relying only on organizational activities to manage stress will not produce the desired, longterm results without incorporating the methods and techniques used to eliminate and reduce stress at the individual level (Munz, Kohler and Greenberg, 2001). Stress elimination and reduction activities should include both organizational and individual level, as well as the interaction between them (Hurrell, 1995).

Depending on the time of application, stress management methods and techniques can be: primary, secondary, and tertiary (Lamontagne, Keegel, Louie, Ostry and Landsbergis, 2007; Richardson and Rothstein, 2008). The old adage "Better safe than sorry" should be applied to workplace stress as well (Stranks, 2005). The primary forms of stress elimination are proactive - they eliminate workplace stressors that can cause work-related stress. Key activities that are implemented in organizations include job redesign and increase in employee independence when performing their tasks and activities.

In addition to the primary forms of stress elimination, different forms of secondary methods and techniques are applied in organizations. They aim to change the way individual reacts to the workplace stressors. This form of stress elimination aims to prepare an individual to adequately deal with stressors if SCHOOL OF BUSINESS, 1/2019, 130-144 
confronted with them, in order to avoid more serious problems in the functioning and work. The third form of stress elimination is tertiary and it aims to reduce the consequences of exposure to stress. Professionals dealing with workplace stress elimination and management have become aware that they need to build a set of stress management techniques for all those employees who have already been exposed to stress.

\subsection{SECONDARY AND TERTIARY STRESS MANAGEMENT AT THE INDIVIDUAL LEVEL}

Secondary methods and techniques for stress elimination and reduction provide employees with the necessary knowledge and skills to identify the stressors they are exposed to and to better manage workplace stress.

Secondary stress management methods and techniques are based on raising employees' awareness of the effects and impact of stress and developing skills to recognize workplace stress. Conferences/seminars/workshops that deal with the consequences and manifestations of workplace stress raise employee awareness about the occurrence and consequences of stress, while employee skills are developed through various courses about change, time, stress, conflict management, work-life balance.

Tertiary stress management methods and techniques refer to the rehabilitation of employees who are exposed to stress and their involvement in daily workflows and activities. This type of method and technique usually involves working with employees individually and helping them recover from stressful situations. It is necessary to define several different approaches to stress management because each employee is unique and his reaction to stress depends on his personal characteristics and circumstances (Sutherland and Cooper, 2002). Some of the methods and techniques at the individual level that have proven to be effective in practice are: time management, physical activity, relaxation techniques, talking with friends and family (Van Der Hek and Plomp, 1997; Robbins and Judge, 2017).

Physical activity is an ideal way to eliminate and reduce stress - walking, jogging, cycling, yoga, aerobics, swimming, team sports, etc. Relaxation techniques such as different forms of deep breathing and meditation aim to reach a level of general relaxation and to direct all your energy to the relaxation of muscles and thoughts. Affirmations in the form of positive sentences and thoughts are also a useful tool for eliminating stress, as this encourages positive thoughts and increases self-confidence. Active socializing and talking with friends, family, and therapists are also considered suitable methods for eliminating or reducing stress (Lukić, 2019). Some authors recommend nutritional changes - increased consumption of foods rich in vitamins A, B, C, 
E, flavonoids, magnesium, and selenium, with an increased amount of fruits, vegetables, whole grains (Bešlić and Bešlić, 2008).

Key activities that can help employees to better manage their time and avoid stressful situations caused by deadlines are (Marič and Žnidaršič, 2018):

- Forming a list of tasks and activities to be performed on a daily and/or weekly basis and setting priorities;

- Eliminating distractions and time-wasters;

- Balancing the requirements and obligations of working and private life because optimal work-life balance has impact on every person.

When it comes to managing stress at the individual level, keeping a diary is particularly important, which means that the employees should record key stressful events in their lives and at work. In this way, an employee can perceive the key stressors and his reactions to them (Richardson and Rothstein, 2008).

\subsection{PRIMARY STRESS MANAGEMENT AT THE ORGANIZATIONAL LEVEL}

There are various strategies for eliminating or reducing workplace stress at the organizational level. Having reviewed the literature, the following methods and techniques for eliminating and reducing stress at the organizational level were identified (Sutherland and Cooper, 2002):

1. Macro-level methods and techniques: changing organizational culture, leadership style, physical working conditions, career development programs;

2. Micro-level methods and techniques: job redesign, various work contracts, effective communication system, assigning roles to employees and team members, increasing the autonomy and ability of employees to independently make decisions related to their segment of work.

Psychological perception of personal autonomy, as research shows, has an important role when it comes to stress resilience (Deci, Olafsen and Rian, 2017). In addition to the psychological need for a sense of competence and belonging in the work environment, the perception of a degree of personal autonomy in business is very important for the efficiency and profitability of an organization, although this usually happens indirectly, through building an optimal psychological balance at work and resilience to stressors. The psychological needs for autonomy, competence, and belonging are considered essential for the optimal psychological functioning of an individual in any environment, even when it comes to working (Mladenović and Čizmić, 2017). The effect of stress reduces if the organization pays attention to the degree of 
self-perception of employees' personal autonomy. The first step is to show appreciation and respect for the employee as a person. Once employees see the appreciation and respect, this will increase the perception of self-worth in the context of work. In this way, positive capacities of the personality are strengthened, thus creating a positive psychological resource for overcoming stressful situations. The next step is to increase the individual's decision-making ability at work. There are jobs that allow for a greater or lesser degree of direct autonomy in decision-making, but when a person is empowered with received respect, it is possible to maximize freedom for making decisions within the boundaries defined by work. The highest degree of employee autonomy would relate to situations in which he or she can participate in the decision-making process at a higher level.

Some studies show that respect for employee autonomy is important especially in young organizations compared to those that exist for a longer period of time. Fostering autonomy has had a positive impact on job commitment, job satisfaction, and work performance, while preventing burnout effect and absenteeism (Preenen, Oeij, Dhondt, Kraan and Jansen, 2016). Studies that also examine the need for competency and belonging show that meeting those needs is associated with greater satisfaction at work (Van Den Broeck, Vansteenkiste, DeWitte and Lens, 2008). The development of autonomous motivation creates greater resistance to adverse external influences, which increases stress resilience (Andreassen, Hetland and Pallesen, 2010; De Cooman, Stynen, Van Den Broeck, Selsl and DeWitte, 2013).

Opportunities for stress elimination at the organizational level can be viewed from many different segments of human resource management and organizational processes. These are: the selection of employees, setting adequate goals, improving organizational communication, wellness programs, stress management training.

Selection of employees. Some jobs are more stressful than others, and every person and employee reacts differently when exposed to stressful situations. During the selection process, candidates should be carefully selected according to their psychological and personal characteristics. Employees who prefer routine jobs and clear rules and procedures should be assigned to such jobs, while those employees who prefer a high degree of autonomy and dynamic work should be assigned to jobs with such characteristics.

Setting adequate goals. Employees who clearly understand goals and find them logical, know how to channel their energy into their realization. In addition, it is important that the goals are ambitious but realistic and achievable.

Improving organizational communication. The intensification of formal channels of communication within an organization reduces the level of SCHOOL OF BUSINESS, 1/2019, 130-144 
uncertainty and ambiguity of employees' roles. Organizing regular team meetings and various team-building activities can enhance communication within the organization.

Wellness programs. Organizations are increasingly supporting various wellness programs. These programs are most often designed as a form of assistance and advisory support for employees to quit cigarettes, alcohol, regulate their weight and improve their diet.

Stress management training. In many organizations, there are stress management training programs with the aim to completely eliminate or reduce workplace stress (Richardson and Rothstein, 2008). The concept of this training is to empower all employees to (Stranks, 2005):

1. Recognize the causes and symptoms of workplace stress;

2. Obtain detailed information about the causes of stress;

3. Take up concrete activities to eliminate and reduce stress;

4. Make decisions about the specific strategies they will implement to cope with stress.

Stress management training should be attended by employees from the human resources sector who deal with stress management, but also by all other employees in the organization. Unfortunately, attendance at this training is often on a voluntary basis, which is why few employees sign up to attend (Munz, Kohler and Greenberg, 2001).

The above mentioned primary stress management methods and techniques for employees at the organizational level require time, energy, management commitment, financial and technical resources and are the result of a planned change within the organization.

\section{CONCLUSION}

As organizations are becoming flexible and agile, there is a growing need for employees who are able to quickly adapt to changes, acquire new knowledge and skills, successfully collaborate with others, and find ways to achieve the best possible results in new and uncertain situations and circumstances. Regardless of an individual's profession, work experience, and the stability of the organization he works in, he cannot completely avoid stressful situations. Unfortunately, the old saying "If it's not broken, don't fix it" still describes the behavior of a large number of organizations where corrective measures and activities are taken only after the negative effects of a particular occurrence are felt. Stress management methods and techniques are no exception - it is only when the employees experience negative effects of stress while performing their 
daily work tasks and activities that organizations begin to apply some of their stress management methods and techniques.

This paper presents a holistic approach to workplace stress management, which involves the application of methods and techniques for stress elimination and reduction from two perspectives: depending on the level at which they are applied and the time of application of methods and techniques. When it comes to the levels, stress management methods and techniques can be applied at the individual and organizational levels. As for the time of application, stress management methods and techniques are divided into primary, secondary and tertiary. Only a careful combination of different methods and techniques for eliminating and reducing workplace stress can produce good results in the long run. Workplace stress management should be an integral part of organizational behavior and should cover all business processes and activities of the organization.

\section{REFERENCES}

Andreassen, C. S., Hetland, J., \& Pallesen, S. (2010). The relationship between "workaholism", basic needs satisfaction at work and personality. European Journal on Personality, 24(1), 3-17.

Balkan, M. O., \& Serin, A. E. (2014). The Effect of Organizational Stress on Individual Performance: A Study on Hospital Staff. International Journal of Business and Social Research, 4(2), 100-111.

Bešlić, I., \& Bešlić, D. (2008). Stres na radu. Škola biznisa, 2/2018, 168-173.

Beltman, S., Mansfield, C., \& Price, A. (2011). Thriving not just surviving: A review of research on teacher resilience. Educational Research Review, 6(3), 185-207.

Britt, T. W., \& Jex, S. M. (2015). Thriving under Stress, Harnessing Demands in the Workplace. Oxford: Oxford University Press.

Brun, J. P., \& Martel, J. (2005). Mental Health at Work - From Defining to Solving the Problem - Preventing stress in the workplace. Universite Laval.

Claridge, B., \& Cooper, C. L. (2014). Stress in the Spotlight, Managing and Coping with Stress in the Workplace. New York: Palgrave Macmillan.

Childs, J. H., \& Stoeber, J. (2012). Do you want me to be perfect? Two longitudinal studies on socially prescribed perfectionism, stress and burnout in the workplace. Work \& Stress, 26(4), 347-364. 
Dar, L., Akmal, A., Naseem, M. A., \& Khan, K. (2011). Impact of Stress on Employees Job Performance in Business Sector of Pakistan. Global Journal of Management and Business Research, 11(6), 1-4.

Deci, E. L., Olafsen, A. H., \& Ryan, R.M. (2017). Self-determination theory in work organizations: the state of a science. Annual Review of Organizational Psychology and Organizational Behavior, 4, 19-43.

De Cooman, R., Stynen, D., Van Den Broeck, A., Sels, L., \& DeWitte, H. (2013). How job characteristics relate to need satisfaction and autonomous motivation: implications for work effort. Journal of Applied Social Psychology, 43(6), 1342-1352.

Ivancevich, J. M., Matteson, M. T., Freedman, S. M., \& Phillips, J. S. (1990). Worksite stress management interventions. American Psychologist, 45, 252-261.

Grawitch, M. J., Ballard, D. W., \& Erb, K. R. (2015). To Be or Not to Be (Stressed): The Critical Role of a Psychologically Healthy Workplace in Effective Stress Management. Stress and Health, 31, 264-273.

Holton, M. K., Barry A. E., \& Chaney J. D. (2016). Employee stress management: An examination of adaptive and maladaptive coping strategies on employee health. Work, 53(2), 299-305.

Hurrell, J. J. (1995). Police work, occupational stress, and individual coping. Journal of Organizational Behavior, 16, 27-28.

Jetha, A., Kernan, L., Kurowski, A., \& Pro-Care Research Team (2017). Conceptualizing the dynamics of workplace stress: a systems-based study of nursing aides. MBC Health Services Research, 17, 1-11.

Johns, G. (2010). Presenteeism in the workplace: A review and research agenda. Journal of Organizational Behavior, 31, 519-542.

Karunanithy, K., \& Ponnampalam, A. (2013). A study on the effect of Stress on performance of employees in Commercial Bank of Ceylon in the Eastern Province. European Journal of Business and Management, 5(27), 87-95.

Kompier, M., \& Kristensen, T. (2001). Organizational Work Stress Interventions in a Theoretical, Methodological and Practical Contex. In Dunham, J. (ed.), Stress in the Workplace: Past, Present and Future (164-191). WHURR Publishers.

Lamontagne, A. D., Keegel, T., Louie, A. M., Ostry, A., \& Landsbergis, P. A. (2007). A Systematic Review of the Job-stress Intervention Evaluation Literature, 1990-2005. International Journal of Occupational and Environmental Health, 13(3), 268-280.

SCHOOL OF BUSINESS, 1/2019, 130-144 
Lazarus, R. S. (1991). Emotion and Adaptation. Oxford: Oxford University Press.

Lazarus, R. S., \& Folkman, S. (2004). Stress Assessment and Coping. Jastrebarsko: NakladaSlap.

Lazarević, S., \& Lukić, J. (2018). Team Learning Processes and Activities in Organization: A Case Study. Economic Themes, 56(3), 301-319.

Lukić J., \& Vračar, M. (2018). Building and nurturing trust in virtual project teams. Strategic Management International Journal of Strategic Management and Decision Support Systems in Strategic Management, 23(3), 10-16.

Lukić, J., \& Lazarević, S. (2018). Sources of Workplace Stress in Service Sector Organizations. Facta Universitatis: Series Economics and Organization, 15(3), 217-229.

Lukić, J. (2019). Znanja i veštine neophodne za upravljanje socijalnim preduzećem. U: Jovanović, J. (ur.) Socijalno preduzetništvo 1. Početni kurs - Kako pokrenuti socijalno preduzeće (84-100). Beograd: Udruženje Limitless.

Maddi, S. R., \& Khoshaba, D. M. (2005). Resilience at Work: How to Succeed no Matter What Life Throws at You. AMACOM.

Marič, M., \& Žnidaršič, J. (2018). The Effect of Gender, Age and Academic Rank on Work-Life Balance. School of Business, 2/2018, 1-11.

Mequilibrium (2013). The Cost of Stress in Your Organization \& What You Should Do About It, New Life Solution. Retrieved from https://www.mequilibrium.com/wp-content/uploads/2013/03/3-1-13FINAL.pdf

Mills, P. R., Kessler, R. C., Cooper, J., \& Sullivan, S. (2007) Impact of a health promotion program on employee health risks and work productivity. American Journal of Health Promotion, 22(1), 45-53.

Mladenović, M., \& Čizmić, S. (2017). The influence of global motivational orientation and needs for autonomy, competence and relatedness on work motivation. Journal of Anthropological Society of Serbia, 52, 63-74.

Munz, D. C., Kohler, J. M., \& Greenberg, C. I. (2001). Effectiveness of a Comprehensive Worksite Stress Management Program: Combining Organizational and Individual Interventions. International Journal of Stress Management, 8(1), 49-62. 
NIOSH - The National Institute for Occupational Safety and Health (1999). Publication Number 99-101. Retrieved from http://www.cdc.gov/niosh/docs/99-101/

Ongori, H. (2007). A Review of the Literature on Employee Turnover. Africa Journal of Business Management, 1(3), 49-54.

Ongori, H., \& Agolla, E. (2008). Occupational Stress in Organizations and Its Effects on Organizational Performance. Journal of Management Research, 8(3), 123-135.

Petković, M., \& Lukić, J. (2013). The impact of information technology on organizational design: Example in health organization. Sociologija, 55(3), 439-460.

Petković, M., \& Lukić J. (2014). New Organizational Forms Supported by the Information and Communication Technology: The Case of Serbian ICT Industry. Facta Universitatis - Economics and Organization, 11(2), 101115 .

Preenen, P.T.Y., Oeij, P.R.A., Dhondt, S., Kraan, K.O., \& Jansen, E. (2016). Why job autonomy matters for young companies' performance: company maturity as a moderator between job autonomy and company performance. World Review of Entrepreneurship, Management and Sustainable Development, 12(1), 74-100.

Risher, H., \& Stopper, W. G. (1999). Current practices. Human Resource Planning, 22(2), 8-10.

Richardson, K. M., \& Rothstein, H. R. (2008). Effects of Occupational Stress Management Intervention Programs: A Meta-Analysis. Journal of Occupational Health Psychology, 13(1), 69-93.

Robbins, S., \& Judge, T. (2017). Organizational Behavior. Pearson, Global edition.

Stickle, F., \& Scott, K. (2016). Leadership and Occupational Stress. Education, 137(1), 27-38.

Stranks, J. (2005). Stress at Work, Management and Prevention. Elsevier.

Sutherland, V. J., \& Cooper, C. L. (2002). Strategic Stress Management, An Organizational Approach. New York: Palgrave Macmillan.

Tillman, J., Hamill, L., Dungan, B., Lopez, S., Lu, S., \& Limeade (2017). Employee Stress, Engagement, and Work Outcomes. Retrieved from https://www.limeade.com/content/uploads/2017/04/EMPLOYEESTRESS-ENGAGEMENT-AND-WORK-OUTCOMES.pdf 
Valcik, N. A., \& Benavide, T. J. (2011). Practical Human Resources for Public Manages - a Case Study Approach, American Society for Public Administration. CRC Press, Taylor \& Francis Group.

Van Der Hek, H., \& Plomp, H. N. (1997). Occupational stress management programmes: a practical overview of published effect studies. Occupational Medicine, 47(3), 133-141.

Van Den Broeck, A., Vansteenkiste, M., DeWitte, H., \& Lens, W. (2008). Explaining the relationships between job characteristics, burnout, and engagement: The role of basic psychological need satisfaction. Work Stress, 22(3), 277-294.

Wagner, A. J., \& Hollenbeck, R. J. (2002). Organizational Behavior. Fort Worth: Hartouct College Publishers.

Delivered: 23.05.2019. Accepted: 04.12.2019. 